\title{
Розин В.M.
}

\section{Из истории становления эзотерических учений}

\begin{abstract}
Аннотация: В статье рассматривается история суффизма и исихазма, которые трактуются автором как эзотерические учения. Вначале характеризуется как автор понимает, что такое эзотерическое учение. Важной предпосылкой эзотерики выступает личность, которая открывает подлинную реальность, соответствующую ее мечтам и высиим ценностям. Разводятся религиозные и эзотерические представления и способы спасения, рассматривает один важный вариант эзотеризма, где подлинная реальность понимается как Бог. Еще один вариант эзотеризма - мистика, когда подвизающийся в спасении добивается непосредственного контакта и встречи с Творцом. Автор показывает, что исихазм и суфбизм тоже начинают выдающиеся личности, выходящие на идею непосредственной встречи с Богом. Развитие этих эзотерических учений проходит три основные этапа: становления учения, когда формулируются его основные идеи, которые и реализуют подвижники, омассовления, предполагающее создание своего рода сакральной технологии и, наконец, слияния и с исходной «материнской» религией (исламом и праославием). Осуществляя историческое исследование, автор реализует методологию культурно-исторической реконструкции, предполагающую в том числе проблематизацию и сравнительный анализ. На основе проведенного исторического исследования удается охарактеризовать особенности эзотерического пути и представлений, развести эзотеризм и религию, показать роль личности в становлении раннего эзотеризма, описать три основные этапа становления эзотерики, а также его схождение с материнскими религиями, в результате чего изменяются как эзотерические, так и религиозные учения.
\end{abstract}

Review: The article is devoted to the history of Sufism and Hesychasm that are interpreted by the author of the article as esoteric teachings. First of all, the author offers his definition of what the term 'esoteric teaching' means to him. According to the author, an important prerequisite for esotericism being formed is a personality of a man who discovers the true reality in accordance with his own dreams and supreme values. The researcher explains the difference between religious and esoteric concepts and ways of salvation and describes a very important esoteric teaching which views God as the true reality. Another esoteric teaching is mysticism when a person seeking salvation tries to contact or to meet God. Development of these esoteric teachings has the three basic stages: the stage of creation when the main ideas are being formulated and realized by followers, the stage of popularization when some kind of a sacral technology is being created, and, finally, the stage of confluence with the initial 'mother' religion (Islam or Orthodoxy). Carrying out his historical research, the author of the article applies the methodology of the cultural and historical re-enactment which includes, among other research methods, the method of problematization and the method of comparative analysis. The results of the historical research allow to describe special features of the development of esoteric opinions, to understand the difference between esotericism and religion, to show the role of personality in the development of early esotericism and to describe the three basic stages in the development of esoteric opinions as well as to show that esoteric opinions are still related to their mother religions and therefore both esoteric and religious teachings change as a result of their development.

Ключевъе слова: Суффизм, исихазм, эзотерика, религия, Бог, реальность, личность, эзотерик, учение, знание.

Keywords: Sufism, Hesychasm, esoteric, religion, God, reality, personality, esotery scientist, teaching, knowledge.

\section{Эзотеризм и эзотерическая личность}

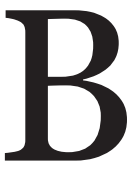
ульфинг фон Рор в книге «Эзотерика» пишет следующее. «Я предполагаю следующее значение термина "эзотерика”: это пути и методы развития личностного сознания, приобщения к всеобъемлющему мировому знанию и достижение здоровья человеческого тела, ума и души в совокупности с определенным способом изложения этой методики. Эзотерический подход существенно отличается от прочих подходов к тем же проблемам: он неортодоксален по отношению к господствующей мировоззренческой системе. Эзотерические постулаты выпадают из рамок общепринятой системы по- 
знания, они пока (еще) не являются (больше) привычной обыденностью жизни<...>

Определение истинной эзотерики дал мой уважаемый и любимый учитель, младший государственный секретарь индийского правительства, мастер медитации, исполненный внутреннего света и вдохновенный поэт Сайт Даршан Сингхджи, определивший ее как "позитивную мистику”, при этом, уточнив, что “негативная мистика” рассматривает мир как нечто дурное или иллюзорное. В таком случае кажется оправданным или даже необходимым оградить себя от этого мира, отказаться от семейных и общественных обязательств и провести остаток жизни в стороне от повседневности, в ските отшельника, постигая тайны своего “я” и спасая свою душу или приближаясь к просветлению. Сант Даршан Сингхджи противопоставляет такой позиции принципы “позитивной мистики”, согласно которым очень важно развитие физического и духовного потенциала человека с пользой для общества. Вместе с тем личность посвящает часть своего времени и отдает свою энергию выяснению духовных истин, пытаясь ответить на вопросы: “Откуда я пришел?”, “Почему я здесь?” и “Куда мне идти?” <...>

Для некоторых людей все, что связано с эзотерикой, представляет собой красную тряпку, повод для раздражения. К сожалению, к их числу принадлежат и церковные деятели, и научно образованные, критически мыслящие реалисты. Церковь часто забывает или не желает замечать того обстоятельства, что большая часть вопросов сегодняшней эзотерики когда-то входила в круг их собственных интересов: поиски смысла жизни и мысли о собственном существовании актуальны всегда и занимают не только верующих» ${ }^{1}$.

Я бы с удовольствием присоединился к этим характеристикам эзотеризма, в которых много верного, если бы не был методологом и культурологом и не посвятил много лет исследованиям эзотерических учений${ }^{2}$. Мой подход к изучению эзотеризма основывается не только на рефлексии эзотерического опыта, что чаще всего имеет место у других исследователей, a, с одной стороны, на герменевтическом отношении, то есть попытке понять эзотери-

1 Вульфинг фон Рор. Эзотерика. http://manyabout. narod.ru/i_e_whatisaezoterika.html.

${ }^{2}$ Розин B.M. Эзотерический мир. Семантика сакрального текста. М., 2002; Каббала в контексте истории и современности (совместно с М. Лайтманом). М., 2005 . ков, уяснить их видение реальности (назовем эту позицию - «внутренней» «герменевтической»), и, с другой стороны, на объективном осмыслении и анализе эзотерического опыта (соответственно, позиция «внешняя», «объективная»). «Объективно» - не означает естественно-научно, для меня объективно - значит в рамках гуманитарного подхода, о котором я много писал. И уже внутри этого подхода при изучении эзотеризма я использую представления культурологии, психологи, семиотики, опять же в том их истолковании, которое я предлагаю в своих работах ${ }^{3}$. Теперь, что я хочу понять и обсуждать.

Вульфинг фон Рор прав, обращая внимание на напряженные отношения многих представителей церкви с эзотериками. За примерами здесь не надо ходить далеко. Когда известный шведский ученый и инженер XVII в. Эмануэль Сведенборг, оставив научные занятия, стал рассказывать, как на самом деле устроены Господь, ангелы, небеса, ад, и при этом существенно разошелся с канонической христианской картиной (так Сведенборг подобно каббалистам не признает троичности существования Бога, зато приписывает ему человеческую телесность, отрицает наличие Сaтаны, не признает воскрешение из мертвых, второе пришествие Христа и Страшный суд, утверждает возможность спасения язычников и существование брака на небесах, иначе, чем церковь объясняет явление Христа), его не только пытались объявить еретиком, но и посадить в дом для умалишенных ${ }^{4}$. А вот более близкий к нам пример - Павел Флоренский.

Что из себя представляет учение Павла Флоренского, изложенное в его первой книге «Столп и утверждение истины», доставившей, как известно, Флоренскому имя и широкую известность в религиозных и философских

\footnotetext{
${ }_{3}^{3}$ Розин В.М. Культурология. М., 2003-2005; Психология: наука и практика. М., 2005; Семиотические исследования. М., 2001.

4 «В последние годы жизни Сведенборг испытал гонения от шведского духовенства, раздраженного его резкой критикой протестантских догматов. В 1769 на сейме шла речь о необходимости признать Сведенборга помешанным и лишить свободы. Чины духовного сословия, предводимые племянником Сведенборга, епископом Филениусом, постановили секвестировать его книги, а два его последователя, члены консистории, были преданы суду». Однако «вследствие общего уважения к Сведенборгу и заступничества короля дело, перешедшее в сенат, было прекращено» (Соловъев В. Сведенборг // Христианство. Энциклопедический словарь. Т.2. М., 1995. С. 519).
} 
кругах? Рассказ автора о своем «живом религиозном опыте», как он пишет о том в обращении к читателю (и здесь сразу вспоминается «Исповедь» св. Августина) или философское учение? Но может быть, это учение эзотерическое и, поэтому для ортодоксальных православных мыслителей отчасти еретическое? Известно, ведь, что, с одной стороны, поклонники Павла Флоренского в православной церкви ведут борьбу за его канонизацию, но с другой - составилась партия «против», как сказал один из ее представителей: «Кто такой Флоренский? - Пышный букет нераспустившихся ересей!»

Что это за православие, где отношения верующего с Богом опосредуются СофиейПремудростью. «В христианстве, - замечает С.С Хоружий, - эта мифологема не обрела прочного статуса ввиду изначально догматического затруднения: неясно, как София может быть связана с Лицами (Ипостасями) Бога и есть ли вообще место для нее в сфере Божественного (если только не отождествить ее с одной из ипостасей, тем самым лишив самостоятельности)»5. Правда, Флоренский в «Десятом письме: София» пытается связать последнюю не только с троичностью Бога, но с другими православными реалиями - Богородицей, Церквью, Словом Божием, Девством, Человечеством, тварной личностью, но разве это доказательство, может возразить ревнитель православия? Вместо обращения к Священному Писанию и канонам, запутанные рассуждения, которые подстать какому-нибудь эзотерику, а не православному священнику.

А как доказывается Флоренским догмат троичности Бога? Редукцией Бога к Истине и фихтеанско-логическими манипуляциями типа «А есть $\mathrm{A}$ » и «А есть не-А», в результате чего следует вывод, что Троица «есть единая сущность о трех ипостасях <... при всем том, и п о с т а с ь и с ущ н о с т ь- одно и то же» ${ }^{6}$ Если бы Бог был объектом науки, например, логики или естествознания, в этом случае понятно, прибегай хоть не только к логике, математике, истории культуры, философии и сравнительному языкознанию (чем широко пользуется Флоренский), но и другим наукам (правда, почему тогда ты священник?); а так все это выглядит, по меньшей

\footnotetext{
5 Хоружий С.C. О философии священника Павла Флоренского // Флоренский П.А. Столп и утверждение истины (I). Т. 1. М., 1990. С. XII.

${ }^{6}$ Флоренский П.А. Столп и утверждение истины (I). T. 1. M., 1990. C. 49.
}

мере, подозрительно. Даже такой доброжелательный к Флоренскому комментатор как Хоружий замечает: «Разве возможно, в самом деле, средствами формальной логики получить вывод, что безусловно достоверное - это единственно “Троица единосущная и нераздельная"? Почти сразу открывается уязвимость линейной схемы “логистика - пробабализм - подвижничество”»7.

Подобные примеры можно умножать, причем не только на почве христианства, но и других мировых религий 8 . Все это, с одной стороны. А с другой - мы видим, что исихазм какэзотерическоеучениевошелвправославие, что примерно в это же время эзотерическое учение «суфизм» был органично включен в ислам, что на основе эзотерического учения Готамы Будды сложился буддизм как мировая религия. Конечно, подобный синтез эзотеризма и религии давался нелегко, потребовал десятилетий напряженной работы

\footnotetext{
7 Хоружий С. Цит. соч. С. X-XI.

8 Яркий пример - судьба ал-Халладжа, принадлежавшего к ранним суфям, но сегодня мы бы уверенно записали его как мистика и эзотерика. «В 921 г., - пишет Евгений Бертельс, - против него начато было судебное дело, тянувшееся семь месяцев. Он был приговорен к смертной казни, и 26 марта 922 г. его сначала изувечили, избили плетьми, распяли, а потом обезглавили, а тело сожгли. Главной причиной осуждения было его учение о “единении с Богом”. Халладж, признавая непостижимость Божественной сущности, учил о существовании внутри Божества несотворенного Божественного духа (рух натика), духа-слова, который может соединиться с сотворенным духом ищущего единения аскета, причем происходит своего рода частичное воплощение. Так, аскет становится святым (вали) и живым и личным свидетелем реального бытия Бога. В момент такого единения Халладж сказал о себе знаменитое изречение: "Я - творческая истина"<...>
}

Халладж в своем учении действительно вступает в резкое противоречие с рядом догматов ислама. Правоверный ислам не допускает прямого общения человека, хотя бы даже и пророка, с Богом. Всякое общение этого рода мыслится как осуществляемое через ангелов. Однако уже в VIII в. наметились и иные теории. Шиитскому имаму Джафару Садику (ум. 762) приписано, например, такое изречение: “Я не переставал повторять стих Корана в моем сердце, пока не начинал слышать его из уст произносящего его [т.е. из уст Бога]”. Халладж эту самую мысль и развивает. Внутренняя молитва для него ведет к контакту с Божеством, причем в состоянии экстаза сотворенный, написанный по-арабски Коран уже начинает звучать как Коран вечный, подлинная речь Божества» (Бертельс E. Происхождение суфизма и зарождение суфийской литературы // Суфии: Восхождение к истине. М., 2003. С. 505-506). 
и драматических столкновений, но все же он произошел. Обратимся к истории исихазма.

«Живя в Константинополе и бывая на Афоне, который был центром византийского средневекового монашества, - пишет И.И. Соколов, - Варлаам был смущен воззрениями и способом подвижничества византийских исихастов, этих безмолвников и молчальников, отличавшихся замкнутой созерцательностью, проводивших время в молитве и умном делании, и совершенно отрешившихся от интересов мира и промышлявших исключительно о спасении. Такой тип подвижничества, неизвестный западному монашеству, живущему в мире и для мира, показался Варлааму не только странным, но и заслуживающим осуждения. Но представитель западного иночества еще более был смущен, когда один из простодушных афонских калогеров в безыскусной форме сообщил ему, что иноки, посредством особого способа аскетической настроенности, удостаиваются телесными очами видеть свет Божественный и созерцать природу Божию (уверен, они говорили, как некоторые суфии, что видят самого Господа, а не просто «природу» Творца. - B.P.)<...>

(как известно, по просьбе афонских иноков в их защиту против Варлаама выступил Григорий Палама). В спор вмешались и другие лица: Палама нашел себе сочувствие у вселенского патриарха Филофея, царицы Анны и ее сына Иоанна Палеолога, у царедворца, а позднее императора Иоанна Кантакузина и, конечно, в среде византийских, особенно афонских безмолвников, а Варлаам имел сторонников в лице богослова и философа Григория Акиндина и историка Никифора Григоры. Таким образом, составились две партии - варлаамитов и паламитов, - и спор разгорелся с большой силой<...>

(итог этого спора известен) Учение Варлаама как еретическое вызвало осуждение церкви. По поводу него созывались соборы в 1341, 1347, 1351, 1352 и 1368. На этих соборах учение Паламы и его сторонников было признанно согласным с учением церкви, а Варлаам и его ученики анафематствованы»9.

Но и Варлаама можно понять. Возможно ли спасение только для себя, закрыв глаза на страдания мира, возможно ли видеть Господа телесными очами, если он тайна и вообще трансцендентален?

\footnotetext{
${ }^{9}$ Соколов И.И. Палама // Христианство. Энциклопедический словарь. Т.2. М., 1995. С. 274-275.
}

Если эзотерическиеучения могут органично включаться в религиозные воззрения, а часто даже теоретически обосновывать их, то почему тогда законодатели мировых конфессий с таким подозрением относятся к эзотерикам? Или может быть, не ко всем, а только к тем «гениям эзотеризма», которые создают учения, уж очень противоречащие основному религиозному мироощущению, так сказать, разрушающие его? И другое недоумение. Если подвизающийся на эзотерическом пути хочет прийти к Творцу всего, то, как он может убедиться в достижении своей цели и мечты, если, действительно, в самом конце своего пути не лицезрел Господа непосредственно? Мало ли какие состояния просветления и благости переживает исихаст (или суфий), мало ли какие образы его посещают (Как писал Симеон Новый Богослов «самое главное не вдаться бесовскому наваждению и тщеславию, как делают многие, которым кажется будто они зрят в этом занятии райские картины»), может быть, действительно это все прельщения и навеяно Сатаной, а не присутствие Бога? Вот если я увидел Господа своими глазами - другое дело, я уверен, что Он есть, существует.

Теперь, как я понимаю эзотеризм. Для меня эзотеризм связан, прежде всего, с личностью, а последняя с креативностью, с самостоятельным поведением человека, с возможностью самому конституировать свою жизнь. Личностный и креативный аспект человеческого существования подчеркивал Рудольф Штейнер еще задолго до того, как он стал эзотериком.

«Повышение ценности бытия человеческой личности, - пишет он в 1891 г. в докторской диссертации по философии (заметим, что «Очерк Тайноведения» появится почти 20 лет спустя), - это есть цель всей науки<...> Результатом этих исследований является, что истина не представляет, как это обыкновенно принимают, идеального отражения чего-то реального, но есть свободное порождение человеческого духа, порождение, которого вообще не существовало бы нигде, если бы мы его сами не производили. Задачей познания не является повторение в форме понятий чего-то уже имеющегося в другом месте, но создание совершенно новой области, дающей лишь совместно с чувственным миром полную действительность<...> Познание покоится, таким образом, на том, что содержание мира дано нам первоначально в такой форме, 
которая несовершенна, не всецело его содержит, но которая кроме того, что она предлагает непосредственно, имеет еще вторую существенную сторону. Эта вторая, первоначально не данная сторона содержания мира открывается через познание. Таким образом, то, что является нам в мышлении обособленным, это не пустые формы, но сумма определений (категорий), которые, однако, являются формами для остального содержания мира. Только добытый через познание образ содержания мира, в котором соединены обе его стороны, может быть назван действительностью»10.

Что же это за познание, о какой чувственности идет речь, о каком мире говорит Штейнер? Для эзотерической личности познание неотделимо от «свободного порождения человеческого духа», чувственность и мир - принадлежность сознания самого эзотерика, который уверен, что это и есть мир как таковой. Героическими усилиями эзотерик открывает подлинный мир (реальность), противопоставляя его обычному. С этого открытия и начинается эзотеризм.

Зная, что существует подлинный мир, эзотерик уже не может жить, как прежде, но дальнейший сценарий развития событий зависит от сил и устремлений человека, подвизающегося на эзотерическом пути. Одни эзотерики удовлетворяются только знанием подлинной реальности, другие пытаются пройти в новый мир, третьи, убедившись, что со своим старым багажом, обрести подлинную реальность невозможно, даже идут на кардинальную перестройку своей личности. Эту третью стратегию эзотеризма, я называю «классической», ее суть можно передать при помощи трех тезисов:

- Наш обычный мир, культура, разум - неподлинны (неистинны, иллюзорны);

- Существует другой подлинный мир (другая реальность), где человек может найти свое спасение, обрести подлинное существование;

- Человек может войти в этот подлинный мир, но для этого он должен изменить свою жизнь, решительно переделать себя. Жизненный путь эзотерика и сводится к подобной переделке, включающей духовную работу и психотехнику.

Известный эзотерик Индии Шри Ауробиндо Гхош писал, что при первом взгляде на требование радикальной перемены человеческой природы может показаться, что все надежды человечества откладываются на отдаленное

${ }^{10}$ Штейнер Р. Истина и наука. М., 1992. С. 7, 8, 37. будущее, так как превышение нашей нормальной природы - умственной, чувствительной и физической - может показаться слишком трудным предприятием и в настоящее время для человека совсем невозможным. Но даже если бы это было и так, говорит он дальше, все же другой возможности преобразования жизни не существует.

То, что с герменевтической точки зрения выглядит как открытие подлинного мира, с объективной должно пониматься иначе, а именно, как его конституирование, причем обе трактовки правильны и равноценны. И то и другое верно, поскольку в современной культуре (но так было не всегда) наша внешняя позиция ничем не истинней внутренней. Хорошо понимая это, автор эзотерического романа «Дон Хуан» с юмором обыгрывает такую ситуацию.

На вопрос своего ученика Карлоса Кастанеды, летал ли он как птица, или это ему только казалось в необычном состоянии, вызванном приемом «травы дьявола», дон Хуан отвечал, что конечно летал. Тогда Карлос Кастанеда, считая, что его полет - это физический процесс, задает вопрос, на который, как он думает, дон Хуан уже не ответит. Он говорит:

«- Давай я скажу это по-другому, дон Хуан. Если я привяжу себя к скале тяжелой цепью, то стану летать точно так же, потому что мое тело не участвует в моем полете?

Дон Хуан взглянул на меня недоверчиво.

- Если ты привяжешь себя к скале, - сказал он, - то я боюсь, что тебе придется летать, держа скалу с ее тяжелой цепью» ${ }^{11}$.

Для дона Хуана, как и для многих эзотериков, нет деления на объективную реальность и субъективные представления, точнее последние для него совпадают с объективной реальностью. В этом случае понятно, почему эзотерики часто пишут, что познание подлинного мира неотделимо от познания и преобразования себя. Спасение себя, говорят эзотерики, это и есть спасение мира.

С объективной позиции, эзотерическая практика не сводится к простым размышлениям: это особый образ жизни, судьба, жизненный путь, страстная устремленность к эзотерическому миру как конечной жизненной цели, приверженность к идеальным формам жизни, известный аскетизм, работа над собой, установка на кардинальное изменение себя самого, горение и напряжение души. Но и особая

${ }^{11}$ Цит. по Розин В.M. Путешествие в страну эзотерической реальности. М., 1998. С. 301. 
культура жизни, включающая в себя разработку эзотерического учения (или освоение его), психотехническую работу над собой (отказ от желаний, отклоняющих эзотерика на его пути, культивирование эзотерического учения, достижение особых состояний сознания, которые и помогают войти в подлинный мир).

При этом нельзя понимать все дело так, что эзотерики сразу рождаются эзотериками. Рождаются они нормальными людьми, мало чем отличающимися от нас с вами. Но в силу мечтательности, устремленности к идеальной жизни, «исторического нетерпения», как выразился один исследователь, возможно, и несколько обостренной чувственности, такой человек рано или поздно начинает ощущать некую другую реальность, очень привлекательную и заманчивую (хотя, с точки зрения автора, этот индивид, подобно К. Юнгу сам эту реальность конституирует в соответствии со своими идеалами и устремлениями; см. первый комментарий в конце книги). Но чтобы маячащая и чаемая реальность состоялась, обрела твердую почву, стала более непосредственной, чем обычная жизнь, оказывается, нужна напряженная многолетняя работа: осознание своих идеалов и экзистенций, отказ от форм жизни и привычек, им не соответствующих, культивирование новых способов жизни, отвечающих эти идеалам, и многое другое, включая идеи подлинной реальности и переделки себя в случае третьей стратегии. Как выразился бы мой друг Андрей Андреевич Пузырей, эзотерик устанавливается в процессе обнаружения и познания эзотерической реальности, причем сами процессы установления, открытия и познания не заданы заранее, а конституируются здесъ же. Поняв, что такое эзотерика, мы можем обсудить ее отличие от религии.

С моей точки зрения, эзотерические учения нельзя отнести к религии, хотя в ряде них речь идет о Творце? В эзотеризме я предлагаю различить один важный тип, который сами эзотерики нередко понимают как религию. Действительно, если эзотерик считает, что именно Бог является подлинной реальностью, то почему, спрашивается, это не религиозная вера? Однако все зависит от того, как Бог понимается. В мировых религиях Древнего мира Бог - сверхсубъект, от желания и настроения которого все зависит. Разгневался, например, Бог на человека и вызвал потоп, кто-то ему понравился - спас от гибели. Формально даже можно помыслить, что Бог (в данном случае христианский) по каким либо обстоятельствам в состоянии изменить свое решение и отменить Конец Света и Страшный суд. Если он, конечно, Бог, который всемогущ и непостижим. В самых древних религиях субъективный характер Творца был более очевиден. Вот, например, горькие размышления о поведении главного бога «учителей» народа «нагуа» (империя ацтеков):

«Господин наш, хозяин непосредственной близости. Думает то, что хочет, решает и развлекается. Как он хотел бы, так и захочет. В центре своей ладони он нас держит и передвигает по своему желанию. Мы движемся, кружимся, как шарики, без направления он нас передвигает. Мы предмет его развлечения: он над нами смеется» ${ }^{12}$.

Однако уже Бог античных философов перестает выглядеть как своенравный субъект. Ему начинают приписываться неизменные свойства, определяющие постоянные особенности его творений. Если у Платона Демиург еще сохраняет некоторые антропоморфные черты, так он создает Космос и человека, поскольку всеблаг, то в работах Аристотеля Бог теряет их окончательно. Аристотелевский бог совпадает с разумом, который мыслит самого себя, причем эта мысль движет планеты по кругу вечным движением. Обсуждая в «Метафизике» природу единого Аристотель пишет:

«Так вот, от такого начала зависит мир небес и <вся> природа. И жизнь <у него> - такая, как наша - самая лучшая, <которая у нас> на малый срок<...> При этом разум, в силу причастности своей к предмету мысли, мыслит самого себя<...> и умозрение есть то, что приятнее всего и всего лучше. Если поэтому так хорошо, как нам, богу - всегда, то это изумительно: если же - лучше, то еще изумительней» ${ }^{13}$.

В средние века Творец понимается не только как создатель мира, но и законы, в соответствии с которыми устроена и действует природа. Попытки приписать ему субъективные характеристики и желания приводили к противоречиям. Действительно, практически все средневековые мыслители обсуждали природу Бога и в связи с этим приписывали ему различные свойства; при этом они, как правило, приходили к парадоксам. Например, Иоанн Скот Эриугена, живший в IX веке, фиксируя эти затруднения, пишет:

12 Леон-Портилья М. Философия нагуа. М., 1961. C. 217-218.

${ }^{13}$ Аристотель. Метафизика. М., -Л., 1934. С. 211. 
«Неужели высшая, простая и Божественная природа принимает какие-либо акциденции (то есть вторичные свойства - B.P.)? - Прочь такую мысль! - Неужели она не сообщает какому-либо предмету акциденции: - <...> И это аксиома. - Стало быть, высшая причина и высшее начало всех вещей, которое есть Бог, не может ни действовать, ни испытывать действие. - Это умозаключение загнало меня в тупик. Если я объявлю его ложным, то сам разум, пожалуй, осмеет меня <...> Если же я признаю его верным, сколь острым стрелам Священного Писания я себя подставляю?» ${ }^{14}$.

В новое время, безусловно, интересное решение этой проблемы принадлежит Канту. С одной стороны, он утверждает, что человек сам «a priori» (т.е. не опираясь на опыт) приписывает природе законы, с другой - что это его творчество обусловлено разумом и ограничено опытом, с третьей стороны, что разум - это не только способность человека, но и действие Творца. Мир по Канту возник из намерения Творца, то есть создан им; одновременно, именно последний в лице разума вносит в мир систему, но конкретно Творецразум реализует себя через деятельность людей, которые сами «a priori» конституируют действительность, но эта свобода их творчества ограничена опытом, за которым, вероятно, стоят как деятельность человека, так и Бог.

Но не сходно ли мыслят, например, каббалисты, утверждая, что сущность Творца непостижима (подобно тому, как непостижима кантианская вещь в себе) и, тем не менее, Творец для нас выступает, с одной стороны, как чистый альтруизм, с другой - как природа (свет и миры), причем, познается, раскрывается последняя с помощью человека ${ }^{21}$.

Бог эзотериков тоже - не своенравный субъект, а особые законы и своеобразная природа, чаще всего духовная. Чтобы убедиться в этом, рассмотрим один пример - представление о Боге Даниила Андреева. Анализируя в «Розе Мира» проблему происхождения зла, Андреев пишет:

«Он (Бог) абсолютно благ. "Он всемогущ” - добавляло старое богословие. Но, если Он всемогущ, Он ответствен за зло и страдания мира, значит, Он не благ. Казалось бы, выйти из круга этого противоречия невозможно. Но Господь творит из Себя. Всем истекающим

\footnotetext{
${ }^{14}$ Неретина С.C. Верующий разум. К истории средневековой философии. Архангельск, 1995. С. 235.

15 Лайтман М., Розин В. Каббала в контексте истории и современности. Изд. 2. М., 2006. С. 287.
}

из Его глубины монадам (монада - это основа души человека, что-то вроде «духовного генома». - B.P.) неотъемлемо присущи свойства этой глубины, в том числе абсолютная свобода. Таким образом, божественное творчество само ограничивает Творца, оно определяет Его могущество той чертой, за которой лежат свобода и могущества Его творений. Но свобода потому и свобода, что она заключает в себе возможность различных выборов. И в бытии многих монад она определялась их отрицательным выбором, их утверждением только себя, их богоотступничеством. Отсюда то, что мы называем злом мира, отсюда страдание, отсюда же то, что эти зло и страдание могут быть преодолены. Законы оберегают мир от превращения в хаос. Сами демоны вынуждены считаться с ними, дабы миры не распались в пыль. Поэтому они не опрокидывают законов, но утяжеляют их. Законы слепы. И просветлены они могут быть не во мгновение ока, не чудом, не внешним вмешательством Божества, но длительнейшим космическим путем изживания богоотступническими монадами их злой воли» ${ }^{16}$.

Оказывается, Бог не всемогущ и ограничен. Но чем? Собственной природой, которая выступает именно как Природа, т. е. имеет неизменные, вечные законы. Таких законов, по меньшей мере, четыре. Первый закон - это закон «творения» (Бог Андреева не может не творить монады, то есть живые существа), второй закон - это поддержание принципа «свободы воли» (его тоже нельзя нарушить, хотя христианский Бог его нарушал и не раз), третий закон - это закон «жизни каждой монады». В соответствии с ним каждая богосотворенная монада проходит определенный жизненный цикл, путь: приобретает материальное облачение, сходит («спускается», как говорит Андреев) в планету или другое космическое тело, участвует в ее жизни, развивается и просветляется, переходя из одних слоев планеты в другие («восхождение» вверх), и, наконец, возвращается просветленной к Богу. Конкретно, на нашей планете человеческие монады - «неделимые бессмертные духовные единицы, высшие “Я” людей» при спуске последовательно приобретают все более плотное «одеяние». Сначала они облекаются в наитончайший материальный энергетический покров, далее из материальности пятимерных пространств создают свой «шельт»,

${ }^{16}$ Андреев Даниил Роза Мира. Метафилософия истории. М., 1991. С. 49. 
затем - астральное тело. И, наконец, четвертый закон, который можно назвать законом «борьбы» светлых сил с темными: подчиняясь ему, Люцифер и демонические силы стараются захватить и разрушить миры, которые создаются Провиденциальными силами.

Зло, считает Андреев, не от Бога, а от Дьявола. Хотя Природа - божественна (это сам Бог и его Творчество), но это именно та Природа, в которой действуют четыре вечных бездушных закона. Но вот интересно, согласился бы христианский Бог вечно следовать этим законам? Сама же реальность жизни на земле (страдания, войны, несправедливость и т. д.), считает Андреев, есть результирующая взаимодействия Бога и дьявола, то есть тоже механическая, законосообразная действительность. В то же время от Бога, как пишет Андреев, только свет, только радость, только спасение.

И в других эзотерических учениях, если утверждается существование Бога как подлинной реальности, последний трактуется природосообразно. Но не будем забывать, что значительно чаще в эзотерических учениях непосредственной реальностью выступает не Бог, а эзотерический мир, неизменный в своих свойствах. Например, у Рудольфа Штейнера - это духовный мир, в котором, кстати, действует Иисус Христос (он «страж порога», помогающий человеку войти в подлинную реальность); у Шри Ауробиндо - эволюция сознания и материи; у Будды - Нирвана и т. д. и т. п. Есть и другие различия.

Религиозное спасение предполагает соборное усилие, обращение к Богу (как бы он ни понимался), признание невозможности кардинального изменения своей души (творит и изменяет душу только Господь). Если эзотерическая реальность понимается как подлинный мир, как духовная природа (частный случай, как мы говорили, особо понимаемый Бог), то религиозная реальность - это Господь, трактуемый как субъект (сверхсубъект); утверждая, что человек создан по образу и подобию Бога, церковь, фактически указывает на субъектность Творца всего. Как субъект Господь - тайна и любовь и много других вполне человеческих действий (он помогает, поддерживает, управляет, наказывает, прощает и т д. и т. п.). Как субъект Господь представляет собой не только порядок и закон, но и свободное действие и даже, иногда, непонятный человеку поступок (см., например, книгу «Утешение философией», написанную перед смертью в тюрьме Северином Боэцием (ок. 480 - 524/526 г.), где последний обсуждает, почему Бог по отношению к Боэцию допускает несправедливость).

Если в религиозной традиции человек спасается не один, а вместе с верующим народом (соборно) и существует общий путь, на котором помогает церковь, верующие, священные книги, то в эзотерической культуре спасение - дело самого подвизающегося на пути, никто ему не может помочь, он бросается в воду и или переплывет море или утонет. Конечно, учитель и община помогают, поддерживают эзотерика, но все равно пройти в подлинную реальность он может только сам; недаром в буддизме всех достигших нирваны называют Буддами.

Наконец, в рамках религии человек приходит к Богу, сохраняя свою личность, а в эзотеризме, проходя в подлинную реальность, он превращается в другое существо. Например, Шри Ауробиндо Гхош считает, что эзотерический человек («гностическое существо») так же далеко отстоит от обычного, как обычный человек от обезьяны.

Если понятно, что я понимаю под эзотерической личностью, и чем эзотерика отличается от религии, можно сделать экскурс в историю эзотерических учений и попытаться продумать дилемму, сформулированную в начале статьи: религия и эзотерика одновременно отрицают и дополняют друг друга, противостоят друг другу и сходятся.

На мой взгляд, система Платона является одним из первых эзотерических учений. Платон утверждает, что существует подлинный мир идей и богов, а цель человеческой жизни состоит в том, чтобы душа припомнила свое божественное существование в мире идей. Если смертный пойдет по этому пути, он спасется, став бессмертным («единым», «мудрым» и «блаженным»).

«Такой человек, - писал Платон в “Послезаконии”, - даже восполнив смертью удел своей жизни, на смертном одре не будет, как теперь иметь множества ощущений, но достигнет единого удела, из множественности станет единством, будет счастлив, чрезвычайно мудр и вместе блажен ${ }^{17}$.

Платон является также одним из первых мыслителей, который способствовал становлению личности, причем платоновская личность ведет не только философский, но и эзо-

\footnotetext{
${ }^{17}$ Платон. Собр. соч. в 4 т. Т. 4. М., 1994. С. 458.
} 
терический образ жизни. Действительно, по Платону именно философ идет по правильному пути, он сознательно строит свою жизнь, вынашивая «духовные плоды», стремясь к прекрасному, благу и бессмертию. Одно из условий такой работы - продумывание своей жизни и переосмысление и изменение ее. В «Государстве» Платон описывает перипетии душ в загробном мире. Вроде бы судьба человека должна полностью определяться богами загробного мира, однако, выбор судьбы (жребия) трактуется Платоном как вполне закономерный, обусловленный тем, как человек жил прежде, в предыдущем цикле. Зависит этот выбор и от личности, оказывается, что отдельные выдающиеся люди способны поменять свою судьбу.

«После этих слов прорицателя сразу же подошел тот, кому достался первый жребий, он взял себе жизнь могущественного тирана (выше богиня судьбы Лахесис, бросавшая в толпу душ жребии, сказала: «Добродетель не есть достояние кого-либо одного, почитая или не почитая ее, каждый приобщается к ней больше или меньше. Это - вина избирающего, бог не виновен». - B.P.). Из-за своего неразумия и ненасытности он произвел выбор, не поразмыслив, а там таилась роковая для него участь - пожирание собственных детей и другие всевозможные беды. Когда же он потом, не торопясь, поразмыслил, он начал бить себя в грудь, горевать, что, делая свой выбор, не посчитался с предупреждением прорицателя, винил в этих бедах не себя, а судьбу, богов все что угодно, кроме себя самого<...> Случайно самой последней из всех выпал жребий идти душе Одиссея. Она помнила прежние тяготы и, отбросив всякое честолюбие, долго бродила, разыскивая жизнь обыкновенного человека, далекого от дел; наконец, она насилу нашла ее, где-то валявшуюся, все ведь ею пренебрегли, но душа Одиссея, чуть ее увидела, с радостью взяла себе» ${ }^{18}$.

Здесь только Одиссей может считаться эзотериком. Он, продумав и пережив прежнюю жизнь, кардинально меняет свою судьбу; меняет, в смысле - творит. Заметим, что в отличие от людей, осуществляющих самостоятельные действия и поступки, боги Платона не своенравны, они задают постоянные условия и законы.

Примерно в это же время складывается личность и на Востоке, причем идеалом для

\footnotetext{
${ }_{18}$ Платон. Государство. Собр. соч. в 4 т. Т. 3. М., 1994. С. $417,418-419$.
}

нее тоже выступает эзотерик - Готама Будда. Будда не только решил, что не желает страдать (стареть, болеть и умирать), но и пришел к мысли об «искуплении», под которым он понимал нахождение способа избежать страданий, познав и изменив реальность. При этом он мыслил в традиции Брахмана-Атмана, слово и знание которого творит бытие. Как гласило древнее изречение: «Брама знает слово и приношение <...> он освобождает свою жизнь от смерти <...> Атман есть все<...> Атман есть весь этот мир <...> Брама есть право<...> Брама есть опора этой вселенной <...> Брама есть слово, истина во слове есть Брама» ${ }^{19}$.

Открыв рецепт спасения (искупления) - отказ от желаний и реальность Нирваны, Будда становится на одну доску с Богом Брамой. Если фигура Будды олицетворяла восточный эзотеризм, то фигура Брамы - индуистскую религию. Каждый из них претендовал на искупление, но совершенно разное. Конфликт был неизбежен. Правда, он был разрешен, верующие в Бога и буддисты пошли на компромисс, но следы этой борьбы мы еще можем разглядеть в преданиях о Будде.

«Открыв знание искупления, пробудившись, Будда пребывает несколько дней на том же месте, под деревом, где произошло озарение, “наслаждаясь блаженством познания". При этом в его душе возникает сомнение: сообщать ли людям то, что он открыл, поймут ли его они. Судя по преданию, сначала он решает этого не делать. И пришло в голову Возвышенного, не поразив его, это изречение, которого до тех пор никто не понимал: “Зачем возвещать миру то, чего я достиг в тяжкой борьбе? Истина остается скрытой для того, кого наполняет желание и ненависть. Когда подумал это Возвышенный, склонилось его сердце к тому, чтобы пребывать в покое и не проповедовать учения"».

Однако подобное решение явно входило в противоречие со вторым аспектом Атмана, Брамой. Брама - Бог, а Бог требует от людей поклонения и служения (жертвы). В ответ он покровительствует людям, несет им жизнь и спасение. Поэтому для восстановления равновесия, нарушенного решением Будды (ведь жертва взаимна), Брама должен был воздействовать на Будду, склоняя его помочь людям. В конце концов достигается компромисс: круг посвященных должен быть ограничен теми, у кого чистые помыслы. Но посмотрим кон-

19 Розин В.М. Эзотерический мир. Семантика сакрального текста. М., 2002. С. 44-69. 
кретно (читая предание), как Брама (одно лицо Атмана) убеждает Будду (представляющего в данном случае другое лицо Атмана) изменить свое решение.

«Тогда узнал Брама Сагампати мыслями своими мысли святого и так сказал самому себе: “Воистину погибнет мир, воистину пропадет мир, если сердце совершенного, святого, высочайшего Будды склонится к тому, чтобы пребывать в покое и не проповедовать учение”.

Тогда покинул Брама Сагампати браманское небо так быстро, как сильный муж выпрямляет свою согнутую руку или сгибает выпрямленную, и он предстал перед Возвышенным. Тогда обнажил Брама Сагампати свое одно плечо от верхней одежды (знак почтения), преклонил правое колено, поднял свои сложенные руки к Возвышенному и так сказал Возвышенному: “Пусть, господин, Возвышенный проповедует учение, пусть Совершенный проповедует учение. Есть существа чистые от праха земного, но если они не услышат проповеди учения, они погибнут; пусть узнают они учение"».

Будда в ответ на требование Брамы выставляет сомнения и заботы, благодаря которым ему кажется бесцельным предприятием проповедовать истину. Брама трижды повторяет свою просьбу; наконец, Будда ее исполняет. «Он сказал:

Да будет всем открыта дверь вечности;

Кто имеет уши, да слышит слово и верует.

Тогда подумал Брама Сагампати: “Возвышенный внял моей просьбе; он будет проповедовать учение". Тогда он преклонился перед Возвышенным, обошел его почтительно и исчез» ${ }^{20}$.

Как мы видим, Будда ничем не ниже Брамы, и они идут на компромисс. Не символизирует ли эта история реальной смычки религии и эзотеризма? Думаю, что так. А вот как такая смычка происходила в каждом конкретном случае, это статья особая. В исихазме, возможно, примерно так, как сошлись религия и эзотеризм, в исламе по-другому, что видно из её истории.

\section{Реконструкция истории становления суфизма}

В исламе становление суфизма и его схождение с религиозными устоями происходили иначе, чем, скажем, формирование исихазма

\footnotetext{
${ }^{20}$ Там же. Стр. 52-56.
}

в православии. Аллах все же существенно отличается от христианской Троицы. Ислам принципиально расходится с христианством в понимании Бога, не приемля христианского догмата троицы, считая его уступкой многобожию. Основа ислама в утверждении, что Бог не только Един, но и Единственен. В связи с этим, исламское вероучение отрицает идею воплощения. Иисус по вере мусульман, не Божественное лицо, а только избранный пророк и посланник Божий (как Авраам, Моисей и Мухаммад). В Коране сказано: «Он - Аллах, нет божества, кроме Него, царь, святой, мирный, верный, охранитель, великий, могучий, превознесенный (59:22-23)<...> Аллах - един, Аллах вечный, не родил и не был рожден, и не был ему равным ни один! (112:1-4)<...> Хвала же Господу твоему, Господу величия, превыше Он того, что они Ему приписывают» (37:180) С точки зрения мусульман, Аллаха нельзя понимать антропоморфно (Бог - не тело и не располагается в пространстве), Он - творец всего, истина (знание), воля и могущество.

В любой религии при ее формирования намечаются два пути к Богу: обычный в рамках социальных институтов, например, церкви, предполагающий обычную жизнь с ее трудами и заботами, и индивидуальный, избранный, требующий от человека посвятить свою жизнь, главным образом, спасению души. Во втором случае подвизающийся считает, что он должен оставить обычную жизнь и сосредоточится на работе, приводящей наикратчайшим путем к Богу ${ }^{21}$. Это и есть идеал спасения, на

\footnotetext{
${ }^{21}$ Несмотря на всю сложность каббалистических построений, в основе этого учения лежит достаточно простая картина, укладывающаяся в названный путь. Есть Творец и творение. Творец создал творение как свою противоположность, но желает, чтобы творение пришло к Нему и насладилось этим. Причем пришло само, по собственной воле и желанию. Для этого Творец создал миры и 620 ступеней сокрытия и стимулировал творение («точка в сердце») к духовной работе и стремлению к Творцу. Творение идет к Творцу, а Творец на этом пути поддерживает и направляет творение. Творение преодолевает свой эгоизм, а Творец создает для этого условия, а также чтобы творение не останавливалось на достигнутом. По мере духовной работы, направленной к воссоединению с Творцом, раскрываются и поднимаются миры и ступени, эгоистические желания сменяются альтруистическими. В принципе, считают каббалисты, каждый человек за 6000 лет придет к Творцу, пережив при этом многочисленные перерождения (реинкарнации). Но, если он вступит на путь спасения, указанный каббалой, то достигнет Творца за одну жизнь.
} 
который последовательно и бескомпромиссно выходят, безусловно, немногие. При становлении суфизма одной из причин, предопределившей выбор пути спасения, выступило то обстоятельство, что правящая верхушка мусульманской общины перестала соблюдать Коран и обычаи, сложившиеся еще при пророке Мухаммаде.

«А тут разражаются междоусобицы, правители отступают от заветов веры, льется кровь мусульман. Не удивительно, что весьма многих охватывает ужас, что час возвещенного Пророком возмездия кажется уже близким. Этот страх перед неминуемой расплатой заставляет верующих готовиться к близкому ответу, отвращаться от всех радостей мира, чтобы избежать кары и получить обещанную награду. Эти настроения, конечно, должны были усугубить внимание к хадисам, заставить верующих все силы устремить на следование Пророку, на самое тщательное воспроизведение всех деталей его частной жизни, какой она рисовалась в идеализированных преданиях (хадисы - это притчи и рассказы, где нормативные положения Корана раскрываются на примерах поступков Пророка или ближайших его лиц. - B.P.).

Таким образом, первыми зачинателями суфийского движения явились суровые ригористы из среды мухаддисов, стоявшие в оппозиции к феодализировавшейся светской власти Омейядов. Термин “суфи” в это время еще не существует. Обычное обозначение для людей этого толка - захид (“отшельник”) или абид (“служитель Божий”). В основе их деятельности не лежит никаких теорий, кроме изложенных выше общих соображений. Их отличия от широких кругов верующих состоят, во-первых, в повышенной интенсивности восприятия религии, во-вторых, в известных чертах религиозной практики. Так, исходя

\footnotetext{
«Человек, - пишет М. Лайтман, - рождается в этом мире, чтобы в течение своей жизни раскрыть для себя высший мир. Тогда он существует в обоих мирах и после смерти тела ощущает духовный мир в той мере, в которой достиг его при жизни в теле. Если в течение своего пребывания в этом мире человек не достиг высшего мира, его душа вновь нисходит в этот мир - облачается в биологическое тело именно для этой цели. Раскрыть высший мир душа может, лишь будучи облаченной в тело. Из этого понятно, что весь этот мир и наше пребывание в нем предназначены только для того, чтобы мы в течение жизни раскрыли высший мир» (Лайтман М. Свобода воли // Исторический аспект науки каббала (Наука каббала. www.kabbalah.info.2004).
}

из таких велений Корана: “и поминайте Меня, дабы Я помянул вас”, они придавали повышенное значение упоминанию имени Божьего, и все свободное время стремились отдавать повторению священного слова. Важное место в их жизни занимало различение между халал (“дозволенным”) и харам (“запретным”). Велись длинные дискуссии на тему о том, какой заработок можно признать в полной мере “халал". Все сходились на том, что всякое даяние, исходящее от носителей власти или от их приближенных, должно безусловно считаться “харам”, так как богатства властителей не заработаны честным трудом, а добыты путем насилия. Все биографии захидов первых веков полны рассказов о том, как эти благочестивые мужи категорически отказывались принять какой-либо дар халифа или его приближенных. Один из них даже считал для себя запретной свою собственную курицу только потому, что она залетела на крышу к соседу-воину из халифской гвардии и поклевала там зерна. Увещевать властителей они считают своим долгом, но принять от них не могут и куска хлеба» ${ }^{22}$.

Нетрудно догадаться, что я буду и здесь утверждать, что именно личность запустила процесс становления суфизма, что первые суфии, как и первые философы и эзотерики на Западе, были теми странными людыми, которые действовали и видели не как все и пытались сами выстраивать свою жизнь ${ }^{23}$. Правда, полностью на почве ислама и веры в Аллаха.

Мусульманен как индивид, показывает Г.Р. Балтанова в книге «Мусульманка», всегда вторичен по отношению к умме, социуму, коллективу. С точки зрения Балтановой, автономная личность, независимая от общественного мнения, от среды в мусульманской культуре если не редкость, то не идеал. Человек абсолютно автономен только в вопросах веры в том смысле, что он несет ответственность перед Всевышним. Во всех остальных вопросах, утверждает автор Мусульманки, он руководствуется нормами исламской уммы. Тот «прайвит спэнс» (частное пространство), о котором так пекутся жители западных стран,

\footnotetext{
${ }^{22}$ Бертельс. Е. Цит. Соч. С. 481.

23 Число выдающихся захидов, считает Бертельс, было, вероятно, не очень велико: на протяжении первых двух веков ислама называют около сорока имен. Но, во-первых, замечает Бертельс, вполне вероятно, что сохранились имена лишь самых крупных представителей движения, а во-вторых, число окружавших их приверженцев было, надо думать, далеко не малым.
} 
имея в виду относительную автономность бытия, говорит Балтанова, на исламском Востоке вряд ли существует ${ }^{24}$.

И, тем не менее, внутри уммы (общины) постоянно возникали отклонения от общей нормы. Читая биографии великих суфиев, невозможно не прийти к выводу - они были яркие личности. Именно из таких людей выходили захиды и абиды. Но что значит прямой путь к Богу? Чаще всего, это убеждение, что несовершенный с точки зрения Корана и хадисов человек должен проделать с собой работу, чтобы приблизиться к идеалу, стать как Мухаммад и другие пророки. Реже, что при этом подвижник, его уже вполне можно назвать «мистиком», должен приблизиться к Аллаху, почувствовать Бога, ведь только в этом случае, считали мистики, можно удостовериться, что Он есть и любит тебя.

«Элемент мистики яснее всего сказывается у знаменитой первой женщины-подвижницы по имени Рабиа ал-Адавиа. Она родилась между 713-718 гг. и умерла в Басре в 801 г. Происходила она из весьма бедной семьи, в раннем детстве была выкрадена и продана в рабство. Однако святость ее жизни дала ей возможность вернуть себе свободу. После ряда лет, проведенных в отшельничестве в пустыне, она пришла в Басру, где около нее собралась значительная группа единомышленников. Крайне интересны сохраненные нам источниками молитвы-импровизации ее, как, например:

“О Господи, звезды светят, сомкнулисъ очи людей, закрыли цари врата свои<...> Всякий влюбленный уединился со своей возлюбленной, а я теперь одна с Тобою. О Господи, если я служу Тебе из страха перед адом, то спали меня в нем, а если служу я Тебе в надежде на рай, изгони меня из него. Если же служу я Тебе ради Тебя самого, то не скрой от меня своей вечной красы”.

Свое отношение к Богу она определяла именно как любовь (махабба): “Так охватила меня любовь к Богу, что не осталось у меня ничего, чем я могла бы любить кого-либо, кроме Него!»<...> Цель любви Рабии - свидание, соединение с Богом. Как она себе это соединение мыслила, установить сейчас трудно. Весьма вероятно, что речь у нее идет о посмертном свидании, а не о тау-хиде позднейших мистиков. Однако если следующее приписываемое ей изречение действительно ей принадлежит, то какие-то представления о возможности

\footnotetext{
${ }^{24}$ Балтанова Г.Р. Мусульманка. М., 2005.
}

прижизненного слияния с Богом у нее быть могли: “Я перестала существовать и вышла из себя самой. Я соединилась с Богом и целиком отдалась ему"»25.

За несколько столетий суфии нащупали и отработали своеобразную «духовную технологию», позволяющую с их точки зрения приводить себя в соответствии с идеалом Мухаммада, а также (это касается только мистиков) вступать в контакт с Высшей Реальностью. Эта технология выращивалась сначала усилиями и подвигом жизни отдельных суфиев, потом рефлексировалась с целью передачи другим подвижникам, наконец, стандартизировалась, если можно так выразиться, с разными вариациями в суфийский общинах. Духовная технология включала в себя три основные элемента: идею самого пути, стоянок и состояний. Стоянки понимались не столько как остановки (это одно из значений, не самое главное), сколько как характеристики духовной работы на определенном этапе пути к Господу. Наконец, состояния позволяли проверять движение и работу на правильность ${ }^{26}$. Приведем один из вариантов подобной суфийской духовной технологии.

«Началом пути, первой стоянкой обычно считается тауба (“покаяние”), т.е. решимость порвать с обычным формальным отношением к шариату и отдаться самоусовершенствованию. Это акт духовного обращения, имеющий для путника исключительное значение.

\footnotetext{
${ }^{25}$ Бертельс. Цит. соч. С. 483-484.

26 «Постепенно рядом с этой практикой начинается своеобразное самонаблюдение, контроль за психическим состоянием. Весьма важную роль в разработке теоретической базы этого самонаблюдения сыграл Абу Абдаллах Харис ибн Асад ал-Анази алМухасиби (род. в Басре, ум. в Багдаде в 857 г.). В отличие от ранних аскетов Мухасиби обладал уже полной богословской подготовкой, а потому мог делать попытки создания точной терминологии своего учения. Написанная им книга «Соблюдение прав Аллаха» излагает в 61 главе основы метода “самонаблюдения” (мухасаба, откуда и прозвание автора). Мухасиби ставит себе задачу проследить соотношение между внешними действиями человека и намерениями его сердца. Крайне тщательный анализ самых сокровенных помыслов и движений души приводит его к установлению понятия “хал" - экстатического состояния, которое, как он полагает, не может быть достигнуто волей самого человека, а ниспосылается ему как божественная милость. Хал, обычно, состояние крайне кратковременное, может быть, даже вневременное, ибо это - мгновенное, внезапное озарение, окрашенное тонами того или иного настроения» (Бертельс. С. 499).
} 
Если в шариате тауба означает сознание греха, раскаяние, желание не повторять этого греха, то в суфийском понимании понятие это углубляется. Изменяется ориентировка человека, наступает полное обращение его помыслов к Богу <...>

Вторым этапом многие авторитеты признают вара (“осмотрительность"). Наиболее характерная черта этого этапа - крайняя скрупулезность в различении дозволенного (халал) и запретного (харам)<...>

Эта осмотрительность естественно ведет к третьему этапу, называемому “зухд” (“воздержанность”). Здесь тоже возможны разные оттенки: можно воздерживаться от греха, от излишка, от всего, что удаляет от Бога, от всего преходящего. В Х в. понятие зухд от отказа от хорошего платья, жилища, пищи, женщин расширяется до отказа от всякого желания и всяческого душевного движения, что уже ведет к упомянутому таваккул, о котором мы скажем подробнее далее.

Четвертый этап - факр (“нищета”). Первоначально это добровольное обречение себя на нужду, обет нищеты, отказ от земных благ, вытекающий как следствие из последовательно проведенного воздержания. Но в дальнейшем и это понятие спиритуализируется. В свете приписанного Пророку изречения: “Нищета - моя гордость”, факр уже понимается не только как материальная бедность, а как сознание своей нищеты перед Богом, т.е. сознание неимения ничего своего, что не проистекало бы от Бога, до психических состояний включительно.

Но поскольку зухд и факр связаны с переживаниями для человека неприятными, из них вытекает пятый этап - сабр (“терпение”) - основная добродетель суфия. Этот термин имеет множество различных определений, суть которых сводится к покорному приятию всего что трудно переносимо. Как говорит Джунайд, "терпение - проглатывание горечи без выражения неудовольствия”. Сабр в высших своих проявлениях приводит к безразличию, спокойному приятию как ниспосланной благодати, так и испытаний<...>

Шестой этап - таваккул (“упование на Бога"). Его начальная стадия состоит в том, что человек отбрасывает от себя всякие заботы о завтрашнем дне, довольствуясь текущим мгновением и уповая на то, что Бог и завтра так же позаботится о нем, как он позаботился о нем сегодня <...> Как мы уже отметили, макамы - состояния устойчивые, достигаемые путем неустанных стараний путника, определенных предпринимаемых им упражнений. Но от внимания суфийских психологов не ускользнуло другое явление душевной жизни - кратковременные настроения, своего рода порывы, налетающие на путника во время прохождения им пути. Эти состояния они обозначили термином “хал" (мн. ч. ахвал), буквально - "состояние, данный момент, преходящее, изменчивое”. Хал, в противоположность макаму, собственными усилиями путника достигнут быть не может. Это - божественная милость, ниспосылаемая свыше и исчезающая так же мгновенно, как возникла<...> Это: 1) курб. (“близость”) - такое состояние, при котором человек ощущает себя как бы стоящим в непосредственной близости к Богу, ощущает устремленные на него взоры Божества; 2) махабба (“любовь”) - волна горячей любви к Богу, подателю всех благ (ср. молитвы Рабии); 3) хауф (“страх”) - припадок ужаса, сознания греховности и неспособности хотя бы в малейшей мере выполнить свои обязанности перед Богом; 4) раджа (“надежда") - проблеск утешения при мысли о милосердии и всепрощении Бога; 5) шаук (“страсть”) и 6) унс (“дружба”) - явления, схожие с любовью, но отличающиеся по характеру и интенсивности; 7) итманина (“душевное спокойствие”) - состояние блаженной уверенности в милости Бога; 8) мушахада (“созерцание") - состояние, в котором человек не только ощущает близость Бога, но как бы и видит Его; 9) йакин (“уверенность”) - высшая степень сознания реальности духовного мира, ничем непоколебимая ${ }^{27}$.

Если каждый суфий - личность и идет своим путем, то почему технология? Ну, вопервых, все они были мусульманами, верили в Аллаха, выросли на Коране и хадисах. Во-вторых, огромную роль в формировании суфизма сыграли секты, кружки, школы, движения, которые иногда даже становились господствующими в социальной жизни. B-третьих, постепенно складывается практика обучения, ориентированная на передачу эзотерического опыта и суфийских представлений от учителя к ученику.

«... суфийская доктрина уже в IX-X вв. превратилась в целую сложную систему. В этот же период возникает и своеобразная общественная организация суфиев. Прохождение тариката (пути) требовало специальных

\footnotetext{
${ }_{27}$ Там же. С. 508-511.
} 
знаний, без которых человек, пытавшийся на свой собственный страх и риск добиться высших, духовных озарений, мог жестоко поплатиться, утратив здоровье и разум. Поэтому уже в ранние эпохи устанавливается обычай, по которому всякий, кто желал посвятить себя этому образу жизни, должен был избрать себе духовного наставника, носившего титул шейх или пир, что означает “старец”. Человек, вступавший под начало шейха, назывался мюрид (от араб. гл. арада - “желать”) - “желающий”, в сущности “вручивший свою волю” (ирада) своему шейху. Мюрид обязан абсолютно покориться воле шейха, всякое указание его выполнять беспрекословно, не размышляя ни о значении, ни о целесообразности его. Именно здесь нередко употребляется выражение: мюрид должен в руках шейха уподобляться трупу в руках омывателя трупов. Искус мюрида начинался обычно с ряда испытаний, имевших целью установить, в какой мере он действительно проникся мыслью покорности. Давались поручения унизительного характера: он должен был обслуживать прочих мюридов, чистить общие уборные, собирать колючки для топлива и т. п.<...> Шейх заставляет мюрида проделывать множество аскетических упражнений, поститься, бодрствовать по ночам, читать Коран в самых трудных и мучительных позах, заставляет его по сорок дней кряду проводить в полном одиночестве в медитациях и молитвах. Постепенно упражнения начинают приобретать иной характер. Шейх перестраивает мышление мюрида на мышление образное, символическое и начинает вновь вырабатывать в нем упорство и волю, способные преодолеть любое препятствие. Понятно, что, занимаясь своего рода экспериментальной психологией, шейхи вырабатывали в себе ряд свойств, в те времена производивших впечатление чудесных, таких как умение вызывать у мюрида гипнотическое состояние, чтение его мыслей и т. д. Такие способности шейха, конечно, создавали ему репутацию святого и чудотворца и содействовали огромному росту его авторитета. Когда шейх видел, что уже ничему новому мюрида научить не может, он давал ему так называемое иджаза - "разрешение" и отпускал его, предоставляя ему самому собрать вокруг себя учеников и продолжать традиции своего учителя. Внешним знаком вступления под начало шейха служило препоясание мюрида особым поясом, дарование ему головного убора, обла- чение во власяницу (хирка) и разные другие обряды, варьировавшиеся в зависимости от различных местных традиций ${ }^{28}$.

В контексте подобного образования и организации жизни индивидуальный опыт отдельного суфия не мог не трансформироваться в социальную технологию. Тем не менее, выдающиеся суфии периодически не могли не расходиться с каноническими основоположениями ислама. Являясь личностями, они осмысляли Высшую реальность и путь к ней в соответствии со своими идеалами и устремлениями. Всего один пример среди множества других - творчество того же Ал-Халладжа.

«Онтология Халладжа обнаруживает явное знакомство его с греческой философией и в основных чертах сводится к следующему. Бог, по его учению, трансцендентен. До начала творения Он беседовал сам с собой, созерцая величие своей субстанции. Так возникла Любовь. Первая манифестация Любви в Абсолюте и определила множественность Его атрибутов и имен. Бог желает созерцать свою Любовь. Он обращает взоры в Предвечность и извлекает оттуда Свое подобие, несущее все Его атрибуты и имена. Это подобие - прачеловек, Адам. Формула «Он - это он» и выражает в сжатом виде всю эту концепцию. В одном из своих стихотворений Халладж выражает эти мысли так:

Слава Тому, кто показал ангелам человечность свою как тайну славы своей сверкающей

божественности,

А затем объявился твари своей

в образе едящего и пьющего.

Так что воочию увидела Его тварь Его, как взгляд, мелькнувший под веком.

Эта концепция совершенно явно сложилась под влиянием христианского учения о богочеловеке. Все стихи Халладжа, которых до нас дошло 150 строк, представляют собой изложенные в прекраснейшей форме беседы его духа с этим божественным Духом о их взаимной любви. Но нужно подчеркнуть, что, в отличие от Рабии, образа плотской любви в поэзии Халладжа нет совершенно. Пламенные стихи эти, при всей страстности их, совершенно лишены какого-либо налета материальности.

Халладж должен был поставить вопрос и о свободе воли, ибо, как мы видели, на всем

${ }_{28}^{28}$ Там же. С. 513-514. 
протяжении IX в. этот вопрос играл исключительно большую роль. Он решает его так: Бог велит нам творить благо, но Он предвидит, что мы сделаем зло. Веление - не сотворено, предвечно, воля - сотворена. Когда Бог приказал Иблису (Сатане. - B.P.) склониться перед Адамом, это был формальный приказ, не веление, иначе Иблис не мог бы не склониться. Таким образом, Бог хочет, чтобы грех был сотворен людьми, но не исходил от них. Сознание этого противоречия - испытание Богом человека. Это противоречие Халладж принимал во всей его силе, и потому-то его и обуревала жажда мученичества. В речах, которые он вел на площадях Багдада в последние годы своей проповеди, он прямо взывал к слушателям, умоляя их помочь ему пострадать.

Таким образом, мы видим, как от эмпирии первых захидов движение через практику приходит к созданию теоретической базы, синкретической в своей сущности и во многом почти непримиримой с правоверием» ${ }^{29}$.

Все попытки современных исследователей понять, что имели в виду суфийские мистики, когда они говорили о своих состояниях при приближении к Высшей реальности, на мой взгляд, не будут убедительными то тех пор, пока мы не поймет (не реконструируем) идеалы и устремления самих мистиков как личностей. Ведь они приписывали Богу именно те свойства, которые им были необходимы, чтобы сделать следующий шаг в собственной эволюции. Соответственно такому пониманию Аллаха они осмысляли и свои состояния.

Говорят, что ал-Холладж заявлял: «Твой дух смешался с моим духом, подобно тому, как амбра смешивается с благоухающим мускусом, мы - два духа, пребывающие в одном теле». Это можно понять не только в том смысле, что для Холладжа ценность любви была наивысшей (для суфиев подобное отношение к любви - общее место), но и так, что Холладж подобно св. Августину ощущал Господа как своего возлюбленного. Учтем к тому же, как Холладж трактовал образ Сатаны. Когда Аллах, создав человека, приказал Сатане поклониться последнему, Сатана отказался, ответив: «Никому другому». Не означает ли такой ответ, что Холладж ощущал себя мессией или даже Христом на почве ислама, что подтверждается и желанием Холладжа в последние годы своей жизни пострадать и принять мученическую смерть.

\footnotetext{
${ }^{29}$ Там же. С. 489-490, 506-507.
}

Стоит обратить внимание еще на один момент. Для многих суфиев само движение к Аллаху и связанные с этим переживания (состояния) становились самоцелью, образом жизни; в этих процессах и реализовалась их личность. В этом случае суфий стремился не столько приблизиться к Творцу, сколько про-живать состояния, вызванные приближением к Нему. Становление подобной, смещенной относительно основной цели спасения, реальности было облегчено, точнее, впервые стало возможным после включения в практику суфизма искусства, прежде всего музыки и танца.

«Одно из этих средств вскоре было признано особо эффективным. Это была музыка, инструментальная и особенно вокальная, сочетающаяся с художественным словом. Слушание музыки было введено в обычай у целого ряда шейхов и получило техническое наименование “сама" (от араб. самаа - “слышать”, букв. “слушание"). Сама не могло не вызвать в правоверных кругах резкого протеста как недопустимое новшество, несовместимое с шариатом, и потому почти все ранние работы по суфизму (X-XI вв.) усиленно обсуждают вопрос о его допустимости. Хотя даже и в самой суфийской среде далеко не все признавали допустимость сама, но все же большинство, в том числе и такие умеренные суфии, как Газали, считали его не противоречащим сунне. Классическим текстом в пользу сама считается обширный раздел “Ихиаулум ад-дин”, посвященный этому вопросу и в сокращенном виде включенный в “Кимиа-исаадат". В этом разделе особый интерес представляет глава, доказывающая, что сама не может быть заменено чтением Корана и дает большие результаты ${ }^{30}$.

По мнению Л. Массиньона, мусульманская духовная традиция так и никогда не оправилась после трагической гибели ал-Халладжа, поскольку была прервана практика, которая зиждилась на сугубо личном и непосредственном мистическом переживании. Это верно, но только отчасти. В такой культуре, которую представлял собой ислам (более широко Восток), творчество личности, расходящееся с общим движением, не могло не создавать колоссальные напряжения. И мы видим, что самые разные учителя и школы начинают работать, чтобы согласовать суфизм с исламом, включить суфиев в общее духовное движение, обогатить на основе суфизма сам ислам. Ведь, с одной стороны, суфии никогда не отрицали свою мусульман-

\footnotetext{
${ }^{30}$ Там же. С. 518-519.
} 
скую принадлежность, а с другой - кто, как не они, шли к Богу наиболее прямым путем и могли передать свой опыт остальным мусульманам. Как мы знаем, усилия ряда выдающихся суфией, работавших над синтезом ислама и суфизма, во многом завершаются творчеством ал-Газали.

«"Оживление богословия” Газали считает возможным осуществить таким путем. Он вводит в правоверие ряд мистических элементов, заимствованных из суфизма, вводит, таким образом, элемент чувства, любви и оживляет закостеневший формализм. Можно сказать, что эксперимент этот ему удался полностью, и что после него сохранилось лишь очень мало представителей самого ригористического правоверия, не пожелавших в той или иной мере последовать за ним. С другой стороны, он подвергает проверке все положения суфизма, выясняет, что из них может быть согласовано с сунной, а что с ней несовместимо, и строит целую умеренную суфийскую систему, в которой элементы иррациональные, экстатические сведены к минимуму и главное внимание уделено внешней обрядовой стороне. Так создается суфизм ортодоксальный, приемлемый для верхушки духовенства, которая становится сильнее, и тем самым сокращается сфера влияния шейхов.

После Газали суфизм перестает быть достоянием одних городских масс. Ему открыта дорога и в феодальный замок. Именно поэтому, как и в силу исторических событий XII в., элементы суфийских учений проникают во все виды литературы и продолжают в какойто мере сохранять такое господствующее положение в течение целого ряда веков» ${ }^{1}$.

Сравнивая между собой разные эзотерические учения, мы видим, что, вероятно, нужно различать, по меньшей мере, два разных вида эзотеризма. В одних уникальные эзотерические учения создают одинокие личности, в значительной мере стоящие в оппозиции как к традиционным религиозным конфессиям, так и к социуму. Таковы, например, эзотерические концепции Кришнамурти, Даниила Андреева, Карлоса Кастанеды. Другой вид составляют эзотерические учения типа исихазма и суфизма. Здесь эзотерическая реальность - это Бог, понимаемый как особая природа, как подлинная реальность. Однако в исихазме роль личности, вероятно, все же выше, чем в суфизме.

Если теперь вернуться к сформулированной выше дилемме, то ее решение очевидно. Религия отрицает только те эзотерические учения и доктрины, которые или еще не проработаны и не приведены в соответствие с религиозными основоположениями, или же делать это не имеет смысла, поскольку расхождения между эзотерической и религиозной картинами (мироощущением) очень велики.

\section{Список литературы:}

1. Андреев Даниил Роза Мира. Метафилософия истории. М., 1991.

2. Аристотель. Метафизика. М.,-Л., 1934.

3. Балтанова Г.Р. Мусульманка. М., 2005.

4. Бертельс Е. Происхождение суфизма и зарождение суфийской литературы // Суфии: Восхождение к истине. М., 2003. Вульфинг фон Рор. Эзотерика. http://manyabout.narod.ru/ i_e_whatisaezoterika.html.

5. Лайтман М. Свобода воли // Исторический аспект науки каббала (Наука каббала. www.kabbalah.info.2004.

6. Лайтман М., Розин В. Каббала в контексте истории и современности. Изд. 2. М., 2006.

7. Леон-Портилья М. Философия нагуа. М., 1961.

8. Неретина С.С. Верующий разум. К истории средневековой философии. Архангельск, 1995.

9. Платон. Собр. соч. в 4 т. Т. 4. М., 1994.

10. Платон. Государство. Собр. соч. в 4 т. Т. 3. М., 1994.

11. Розин В.М. Эзотерический мир. Семантика сакрального текста. М., 2002.

12. Розин В.М. Путешествие в страну эзотерической реальности. М., 1998.

13. Розин B.M. Каббала в контексте истории и современности (совместно с М. Лайтманом). М., 2005.

14. Розин В.М. Культурология. М., 2003-2005; Психология: наука и практика. М., 2005.

\footnotetext{
${ }^{31}$ Там же. С. 517.
} 
15. Розин В.М. Семиотические исследования. М., 2001.

16. Соколов И.И. Палама // Христианство. Энциклопедический словарь. Т.2. М., 1995.

17. Соловьев В. Сведенборг // Христианство. Энциклопедический словарь. Т.2. М., 1995.

18. Флоренский П.А. Столп и утверждение истины (I). Т. 1. М., 1990.

19. Хоружий С.С. О философии священника Павла Флоренского // Флоренский П.А. Столп и утверждение истины (I). Т. 1. М., 1990.

20. Штейнер Р. Истина и наука. М., 1992.

21. Розин B.M. История становления монашества как социального института // NB: Исторические исследования. - 2012. - 1. - С. 212 - 263. URL: http://www.e-notabene.ru/hr/article_335.html

22. И.А. Манев Являются ли реальностью библейские рай и ад? // Философия и культура. 2011. - 2. - C. $42-52$.

23. Самохина Н.Е. Шамбала: миф или загадка истории? // NB: Исторические исследования. 2012. - 1. - C. 1 - 33. URL: http://www.e-notabene.ru/hr/article_243.html

\section{References (transliteration):}

1. $\quad$ Andreev Daniil Roza Mira. Metafilosofiya istorii. M., 1991.

2. $\quad$ Aristotel'. Metafizika. M.,-L., 1934.

3. Baltanova G.R. Musul'manka. M., 2005.

4. Bertel's E. Proiskhozhdenie sufizma i zarozhdenie sufiiskoi literatury // Sufii: Voskhozhdenie k istine. M., 2003. Vul'fing fon Ror. Ezoterika. http://manyabout.narod.ru/i_e_whatisaezoterika.html.

5. Laitman M. Svoboda voli // Istoricheskii aspekt nauki kabbala (Nauka kabbala. www.kabbalah.info.2004.

6. Laitman M., Rozin V. Kabbala v kontekste istorii i sovremennosti. Izd. 2. M., 2006.

7. Leon-Portilya M. Filosofiya nagua. M., 1961.

8. Neretina S.S. Veruyushchii razum. K istorii srednevekovoi filosofii. Arkhangel'sk, 1995.

9. $\quad$ Platon. Sobr. soch. v 4 t. T. 4. M., 1994.

10. Platon. Gosudarstvo. Sobr. soch. v 4 t. T. 3. M., 1994.

11. Rozin V.M. Ezotericheskii mir. Semantika sakral'nogo teksta. M., 2002.

12. Rozin V.M. Puteshestvie v stranu ezotericheskoi real'nosti. M., 1998.

13. Rozin V.M. Kabbala v kontekste istorii i sovremennosti (sovmestno s M. Laitmanom). M., 2005.

14. Rozin V.M. Kul'turologiya. M., 2003-2005; Psikhologiya: nauka i praktika. M., 2005.

15. Rozin V.M. Semioticheskie issledovaniya. M., 2001.

16. Sokolov I.I. Palama // Khristianstvo. Entsiklopedicheskii slovar'. T.2. M., 1995.

17. Solov'ev V. Svedenborg // Khristianstvo. Entsiklopedicheskii slovar'. T.2. M., 1995.

18. Florenskii P.A. Stolp i utverzhdenie istiny (I). T. 1. M., 1990.

19. Khoruzhii S.S. O filosofii svyashchennika Pavla Florenskogo // Florenskii P.A. Stolp i utverzhdenie istiny (I). T. 1. M., 1990.

20. Shteiner R. Istina i nauka. M., 1992.

21. Rozin V.M. Istoriya stanovleniya monashestva kak sotsial'nogo instituta // NB: Istoricheskie issledovaniya. - 2012. - 1. - C. 212 - 263. URL: http://www.e-notabene.ru/hr/article_335.html

22. I.A. Manev Yavlyayutsya li real'nost'yu bibleiskie rai i ad? // Filosofiya i kul'tura. - 2011. - 2. C. $42-52$.

23. Samokhina N.E. Shambala: mif ili zagadka istorii? // NB: Istoricheskie issledovaniya. - 2012. - 1. C. 1 - 33. URL: http://www.e-notabene.ru/hr/article_243.html 